\title{
Research on Stress Distribution Characteristics for Uniquely Shaped Roadway with Hard Roof in Steeply Inclined Coal Seam and Support Technology of Reducing Vibration Impact
}

\author{
Junhui Zhang $\mathbb{D}^{1,2}$ Hui Chen $\mathbb{D}^{1,}{ }^{1,2}$ Xiuzhi Shi $\mathbb{D}^{1},{ }^{1}$ Weiming Guan $\mathbb{D}^{1,2}$ and Xiaolong Sun ${ }^{1}$ \\ ${ }^{1}$ School of Geology and Mining Engineering, Xinjiang University, Urumqi 830046, China \\ ${ }^{2}$ Teaching Demonstration Centre of Mining and Geological Engineering of Education Department of Xinjiang Uygur \\ Autonomous Region, Urumqi 830046, China
}

Correspondence should be addressed to Xiuzhi Shi; baopo@csu.edu.cn

Received 14 May 2021; Accepted 23 June 2021; Published 8 July 2021

Academic Editor: Chao Xu

Copyright ( $\odot 2021$ Junhui Zhang et al. This is an open access article distributed under the Creative Commons Attribution License, which permits unrestricted use, distribution, and reproduction in any medium, provided the original work is properly cited.

This paper presents a comprehensive study of the stress distribution and stability analysis of a uniquely shaped roadway having a steeply dipping hard roof. The coal seam and its roof have a certain impact tendency, which is the internal condition of rock burst. The syncline tectonic stress causes the original rock stress to reach a higher level. The large amount of coal produced in the coal mine and the large movement range of the upper strata cause the huge mining additional stress around the stope. The impact load caused by "cantilever beam" fracture of hard roof can induce and strengthen rock burst. Its engineering geological setting encompasses the mining process and surrounding rock conditions of No. 6 Coal Seam in the 2130 coal mine of Xinjiang. Numerical simulations with theoretical analysis and field measurements investigated a proposed new truss combined support scheme for implementation. A comparison was made of the differences in the state parameters of the road under the new and old support conditions. The application of the new combined support technology changed the form of the stress distribution around the road. Apart from the displacements of the two coal sidewalls, the new support system notably reduced the displacement of roof and floor by $67.8 \%$ and $83.6 \%$, respectively. After the implementation of the new support scheme, the frequency of the original rock burst in the working face is greatly reduced, the surrounding rock control and field application effects also remained good, and personnel and equipment safety and production plan have a good guarantee.

\section{Engineering Geology and Production Conditions}

Steeply inclined coal seam refers to coal seams that have a dip angle greater than $45^{\circ}$. More than $50 \%$ of the coal mines in Southwest China operate in steeply inclined coal seams. Steep coal seams are widely distributed in many coal productions bases in Xinjiang, Gansu, Ningxia, Shanxi, Guizhou, Chongqing, Huainan, and so on. In China's total coal reserves and production over the years, steep coal seam accounts for less than $5 \%$, but there are many production mines. According to incomplete statistics, steeply inclined coal seam mining is distributed in more than 100 production mines in more than 20 key mining areas in China, and $1 / 6$ of the total number of mines in China is steeply inclined coal seam mining. With the focus of national resource development and coal mining shifting to the west, steep coal seam, which accounts for more than $50 \%$ of the number of mines in the west, has become an important mining object. Typical mines are Xinjiang Wudong coal mine, Gansu Yaojie No. 3 coal mine, Gansu Huating coal mine, etc. [1-3]. The main types of coal are coking coal, anthracite coal, and some scarce coal that are indispensable power fuel and industrial raw materials for national and local industrial development. 
To adapt to the rapid growth of China's economy, the proportion of deep coal seams with a large dip angle in coal mining will increase year by year.

Thin coal seams, large dip angles, and multilayering are the main characteristics of the steeply inclined coal seam. The stability of coal and rock masses on the mining road is the premise to ensure safe mining of the working face. Mine road openings usually have a rectangular cross section to meet the stringent transportation requirements set by the mechanized equipment operating in fully mechanized mining faces. Steep inclination angles lead to obtuse angles between the sides and top (roof) of the road and between the roof and floor of the coal seam. Furthermore, the gravity force from the overlying coal and rock resolved along a steeply inclined bedding plane is more critically significant in considering the roadway failure than if the seams were horizontal or gently dipping. The critical areas for stability control of rock surrounding the roadway are also different, the uneven stress distribution caused by special-shaped roadway aggravates the frequency of rock burst, and, hence, it warrants a reasonable stability control method due to the prevailing asymmetric stress distribution in the surrounding rock.

With the continuous mining and consumption of mineral resources, the mining conditions of steeply dipping coal seams have changed from simple to complex. Mining of resources under such adverse conditions with a complex roof is worthy of scientific attention. The resource development processes in steeply dipping coal seam mining faces are more susceptible to complex mechanical problems than the horizontal (or gently inclined) coal seams. These lead to frequent roof fall, rib spalling, and other related safety problems. Some scholars [4-8] believed that the deformation and failure of the rock surrounding roadways (Figure 1) in steep coal seams have asymmetric characteristics. The stress distribution is asymmetric along the centerline of the road, which gives rise to coal sidewall failure and then leads to severe roof subsidence. Such asymmetric failures also include dislocation and subsidence of coal and rock mass at the shoulder corner. Its deformation, failure, and instability are a complex space-time problem. Some scholars [9-12] concluded that an unstable structure shows upward movement with tensional shear failure movement caused by the inclined gravity component for irregular quadrilateral road opening. Similarly, a downward trend of compressional shear occurs with the vertical component of the gravitational action resulting in a final cut or fall, respectively. The equations governing these two failure forms were established and presented together with the assessment criteria.

Taking the uniquely shaped roadway of 2130 coal mine in Xinjiang as the research background, this paper puts forward the common control method of roadway stability based on stress transfer from the roof and high wall vulnerable parts. It optimizes the construction scheme through theoretical analysis with numerical simulation and applies it to engineering practice successfully.

\section{Engineering Background}

The central coal seam of Xinjiang 2130 coal mine was the number 6 coal seam, which was the lowest minable coal seam in this mine. This coal seam dipped to the South, and the strike was near east-west. Observations from excavations at the low horizontal level drainage passage $(+2047 \mathrm{~m})$ and the 26,221-return air passage helped infer that the $3.7 \mathrm{~m}$ thick coal seam contained $0 \sim 3$ layers of gangue. It had a simple to medium structure, with a coal seam dip angle of $35^{\circ} \sim 43^{\circ}$ $\left(\right.$ mean dip of $\left.39^{\circ}\right)$. There was a thin coal line in the number 6 coal seam roof, which led to poor contact between various strata. Roof falling and other accidents may have occurred during tunneling. Hence, the roof support work needed to be strengthened. The direct roof of the coal seam is comprised of coarse sandstone and glutenite. The bedding was the primary form of structure. The rock strength reduced on contact with groundwater when the rock effortlessly softened, causing block collapse. Therefore, measures to strengthen the roof support were deemed extremely necessary. "Strike, long-wall mining method" was adopted on the 26,221-working face. The roof management mode was advanced preblasting to deal with the challenging and complex roofs. Notably, the inclined length of the working face was $148 \mathrm{~m}$, and its dip angle was $38^{\circ} \sim 44^{\circ}$.

The cross section of the driving roadway was trapezoidal, with the taller wall being $4.5 \mathrm{~m}$ high and the height of the shorter wall being $1.5 \mathrm{~m}$. The width of the roadway was $4.0 \mathrm{~m}$. The roof structure of the roadway was simple, the direct roof was $2.0 \mathrm{~m}$ thick glutenite, and the main roof was $15.6 \mathrm{~m}$ thick medium sandstone. The activity at the mining face adopted the comprehensive mechanized backward mining method. It drove the return air passage and the transportation roadway along the roof, and the roof was not broken. The original trapezoidal roadway roof and the coal walls were supported by a conventional bolt (cable) monomer. The roadway roof was hard and had good integrity. Under the existing support conditions, the roof of coal seam has weak impact tendency, and roof fall and rib spalling frequently occurred during the tunneling process, which seriously restricted the safety production of mining enterprises. The most serious roof fall was caused by rock burst with a height of $26 \mathrm{~m}$. The treatment of the roof fall resulted in 32 days shutdown of the mine, resulting in serious losses. Figure 2 illustrates the comprehensive geological stratigraphy of the coal seam, and Table 1 gives the physical and mechanical parameters of coal and rock strata.

\section{Stress Analysis of Uniquely Shaped Roadway}

3.1. Stress Analysis of Roadway Roof. According to the actual geological conditions of the 2130 coal mine, establishing a reasonable mechanical model was the basis of the analysis. The roadway roof was simplified as a simply supported beam structure [13]. Based on the small deflection and elastic thin plate theory, the working face model is established, and the mechanical analysis of the upper main roof of the stope is 

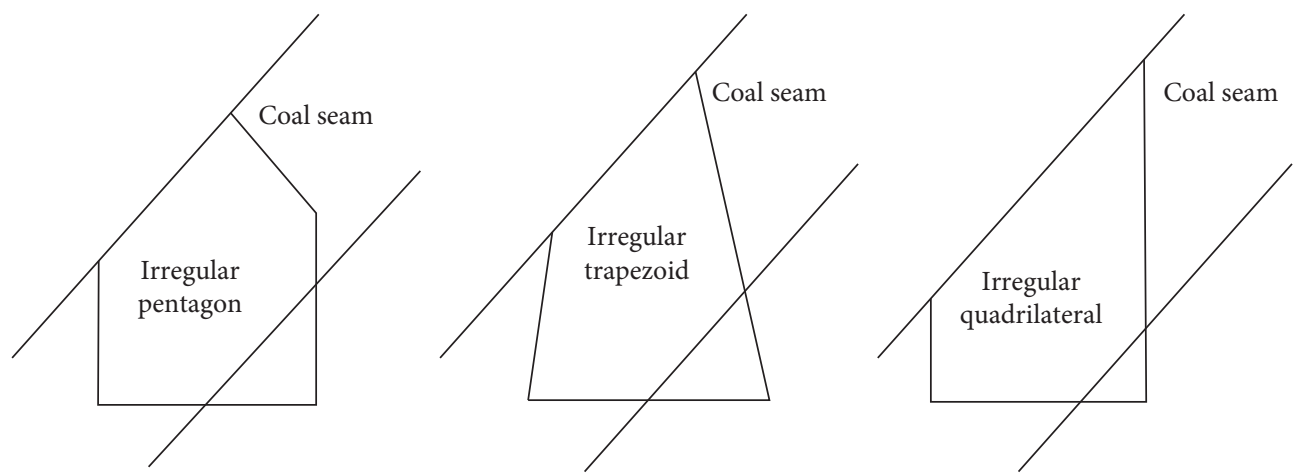

FIgURE 1: Schematic diagrams for typical abnormal roadway cross-sections.

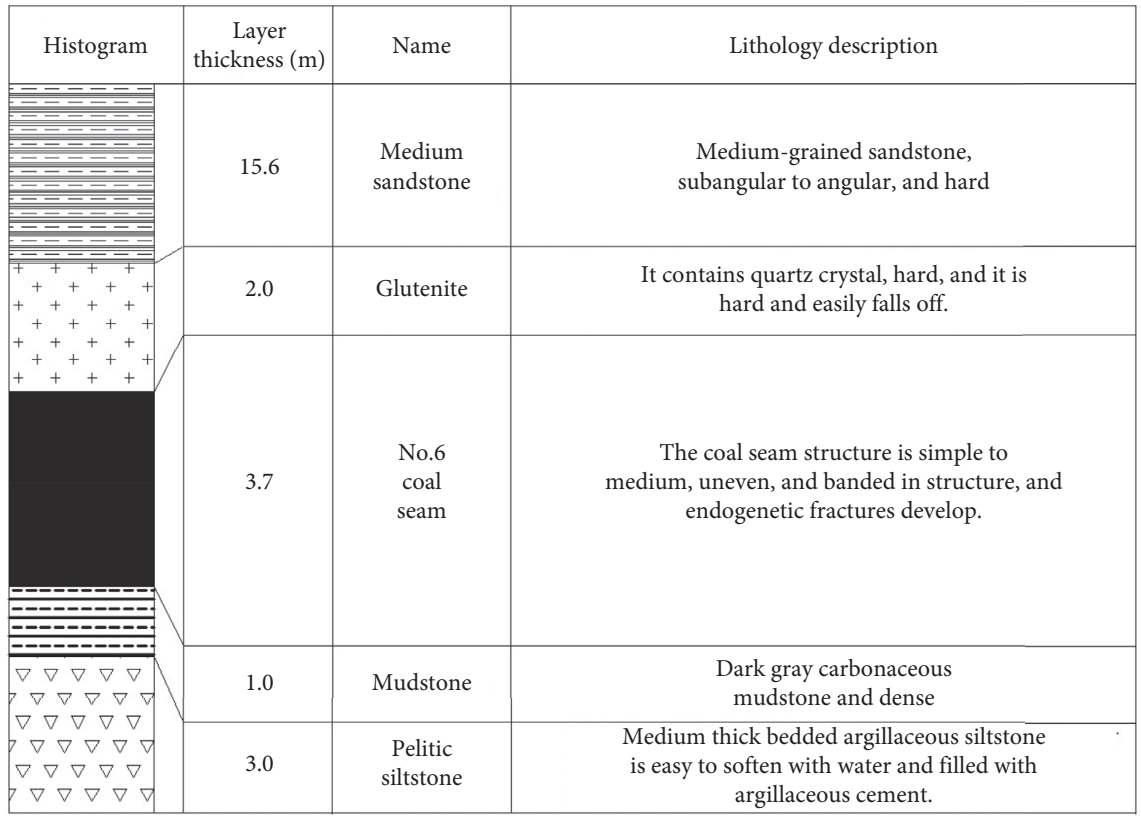

Figure 2: Comprehensive stratigraphic chart for No. 6 coal seam.

TABLE 1: Mechanical parameters of the strata.

\begin{tabular}{|c|c|c|c|c|c|c|c|c|}
\hline Position & Rock stratum & Thickness & $\begin{array}{l}\text { Bulk modulus } \\
\qquad(\mathrm{GPa})\end{array}$ & $\begin{array}{c}\text { Shear } \\
\text { modulus } \\
(\mathrm{GPa})\end{array}$ & $\begin{array}{l}\text { Cohesion } \\
\text { (MPa) }\end{array}$ & $\begin{array}{c}\text { Tensile } \\
\text { strength } \\
(\mathrm{MPa})\end{array}$ & $\begin{array}{l}\text { Friction } \\
\text { angle }\left({ }^{\circ}\right)\end{array}$ & Density $\left(\mathrm{kg} \cdot \mathrm{m}^{-3}\right)$ \\
\hline Main roof & $\begin{array}{l}\text { Medium } \\
\text { sandstone }\end{array}$ & 15.6 & 11.0 & 6.0 & 45.0 & 4.8 & 35 & 2700 \\
\hline $\begin{array}{l}\text { Immediate } \\
\text { roof }\end{array}$ & Glutenite & 2.0 & 8.0 & 4.0 & 30.0 & 3.2 & 32 & 2600 \\
\hline Coal seam & $\begin{array}{l}\text { No. } 6 \text { coal } \\
\text { seam }\end{array}$ & 3.7 & 1.5 & 1.0 & 2.0 & $0.2-1.4$ & 30 & 1500 \\
\hline $\begin{array}{l}\text { Immediate } \\
\text { bottom }\end{array}$ & Mudstone & 1.0 & 2.0 & 1.0 & 5.0 & $0.5-1.2$ & 30 & 2100 \\
\hline Hard floor & $\begin{array}{c}\text { Pelitic } \\
\text { siltstone }\end{array}$ & 3.0 & 3.0 & 2.0 & 10.0 & 2.0 & 31 & 2200 \\
\hline
\end{tabular}

carried out [14]. Unsymmetrical deformation mainly occurs near the weak structural plane and the intersection of roadway section and surrounding rock inclination direction. Based on this, the "unsymmetrical high prestress pressure relief coupling control technology" is proposed, and its analysis and industrial test are carried out. The practice shows that the asymmetric coupling support technology can not only effectively solve the problem of differential deformation of surrounding rock, but also ensure the coordinated deformation of support structure and 
surrounding rock, so as to improve the overall stability of the roadway, greatly reduce the repair rate of the roadway, and save the resource support cost [13-18].

The shorter sidewall was simplified as a fixed hinge support $A$, and the taller sidewall was simplified as a movable hinge support $B$. Figure 3 shows the established mechanical model. In Figure $3 ; F_{1}$ and $F_{2}$ are vertical bearing reaction forces, while $F_{3}$ is the horizontal force at the fixed hinge bearing end. While $q$ is the stress of the upper load acting on the roof, $\rho$ is the rock mass density. $X$ is the horizontal distance between the points $A$ and $B$ and $l$ is the width of roadway. The acceleration due to gravity is $g$ and $\alpha$ is the dip angle of the coal seam.

In an irregular-shaped roadway, with an increased coal seam dip angle, the height of the higher sidewall is increased. The combined action of vertical and inclined stresses caused the two coal sidewalls to be more prone to different levels of damage. The damage degree and scope of the high wall were much larger than those of the low wall, further aggravating the roof settlement and increased risk of roof accidents. Under the combined action of mining depth increase, driving influence, and other factors, the load on the upper part of the roof showed a dynamically increasing trend, and the vertical deformation of the roof continued to increase:

According to the vertical-static equilibrium condition, the roof deflection curve equation was obtained as follows:

$$
\begin{aligned}
& \frac{1}{2} q l \cdot\left(\frac{1}{2} l+\frac{1}{2} p g l^{2}\right) \tan \alpha \cdot \frac{1}{3} l=F_{2} l, \\
& \text { EI } \omega I \frac{1}{24} q x^{4}-\frac{1}{12} q l x^{3}+\frac{1}{24} q l^{3} x \\
& \quad+\frac{1}{120} p g x^{3} \tan \alpha-\frac{1}{36} p g l^{2} x^{3} \tan \alpha+\frac{7}{360} p g l^{4} x \tan \alpha,
\end{aligned}
$$

where $E$ is the elastic modulus of roof rock mass, $I$ is the bending moment of inertia of roof, and $\omega$ represents the deflection of the roof.

Using the lithology parameters and formulas (1) and (2), the deflection relationship between different upper load and roof subsidence was obtained. The roof subsidence was positively correlated with the upper load, and the consequent deflection curve was in the shape of a net pocket. Due to the stress asymmetry on the roof from the uniquely shaped roadway, the bottom of the deflection net pocket curve deviated from the center of the roadway and was closer to the low sidewall. The bottom of the net pocket was the maximum tensile stress on the roof, which was, therefore, the crucial monitoring and protection area. Subsequent numerical simulation and field monitoring also verified this point.

3.2. Stress Analysis of Roadway Coal Wall. Under the influence of tunneling and roof stress transmission, the coal walls of the roadway were easy to form endogenous cracks, and improper support of the roadway facilitated roof fall accidents. Under the influence of vertical stress, the coal walls were prone to slip failure. According to the analysis of the roadway side slip mechanical model [13] and field practice, the middle and upper parts of the higher coal wall were the most vulnerable areas. If the two sides of the coal wall structure were intact, it could support the roof load. If the two coal sidewalls were impaired, the roof could sink as a whole, and the roadway structure will be significantly damaged, which led to roof fall and rib spalling accidents.

The following three technical measures enhanced structural stability and changed the stress state of the roadway. (1) The support anchor point was located in the stable rock layer to bear the roof pressure and to reduce the pressure transfer load of the roof onto the two coal sidewalls. (2) We changed the original support form of roadway, increasing the truss connection between anchor cables to improve the shared bearing capacity between the support structure and the surrounding rock. (3) As per the roadway condition, the pressure relief groove was designed to minimize stress concentration.

Figure 4 shows the overall map of the field roadway under the new truss anchor cable support structure. The roof and two sides of the coal wall are complete without obvious damage. After the implementation of truss support structure, the structural integrity of roadway is good, the deformation of roof, floor, and two sides of roadway is small, and the rock burst phenomenon is significantly reduced, which meets the needs of safety production.

The basic idea of roadway safety control was to transfer the stress of roof and coal wall to the deep coal and rock mass, reduce the stress damage on the coal sidewalls, and improve the safety of the roadway construction, improving the excavation $n$ efficiency and mine production efficiency.

\section{Numerical Simulation Analysis}

4.1. Model Establishment and Parameter Selection. Based on the geological conditions of the roadway, the numerical model of coal and rock strata was established with the FLAC3D software, and the Mohr-Coulomb failure criterion was adopted. Considering the coal seam dip angle and model block size, the final modeling size was $30 \mathrm{~m} \times 35 \mathrm{~m} \times 0.1 \mathrm{~m}$ (long $\times$ width $\times$ high). The block size of the model element was $0.1 \mathrm{~m} \times 0.1 \mathrm{~m} \times 0.1 \mathrm{~m}$ (long $\times$ width $\times$ high). The whole $3 \mathrm{D}$ model was divided into 126,996 units and 218,675 nodes. The roadway section was an irregular trapezoid, and the roadway size was (high side $4.5 \mathrm{~m}+$ low side $1.5 \mathrm{~m}$ ) $\times 4.0 \mathrm{~m}$ (height $\times$ width). Figure 5 illustrates the establishment of the numerical model. Combined with the actual situation of the driving roadway, the vertical displacement of the bottom boundary of the model was set to zero, and the horizontal displacement of the front, back, left, and set right boundaries of the model was set to zero. Considering the influence of self-weight stress of strata, $(2.7 \times 5.3=) 14.31 \mathrm{MPa}$ stress was applied to the overlying strata as the self-weight compensation load uniformly applied to the upper interface of the model.

Numerical simulation of roadway without support, original roadway support, and new truss structure support three forms. In the study of microseismic events and numerical simulation of rock burst mechanism in underground 


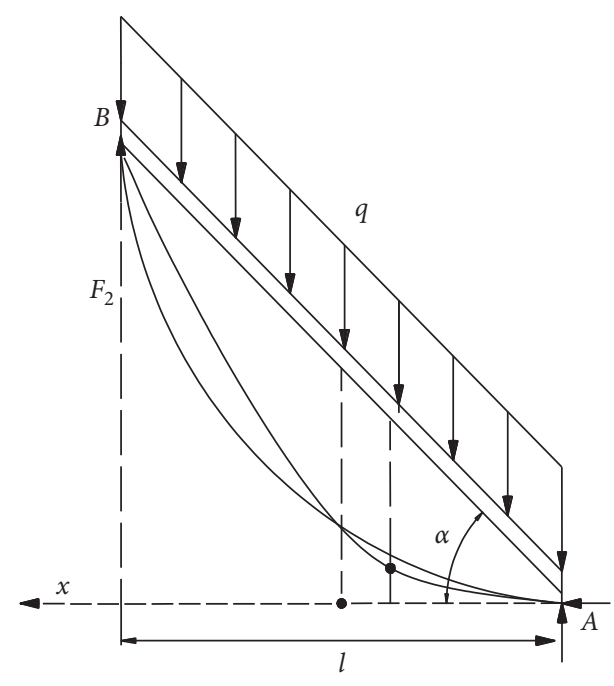

Figure 3: Stress diagram on an inclined roof.

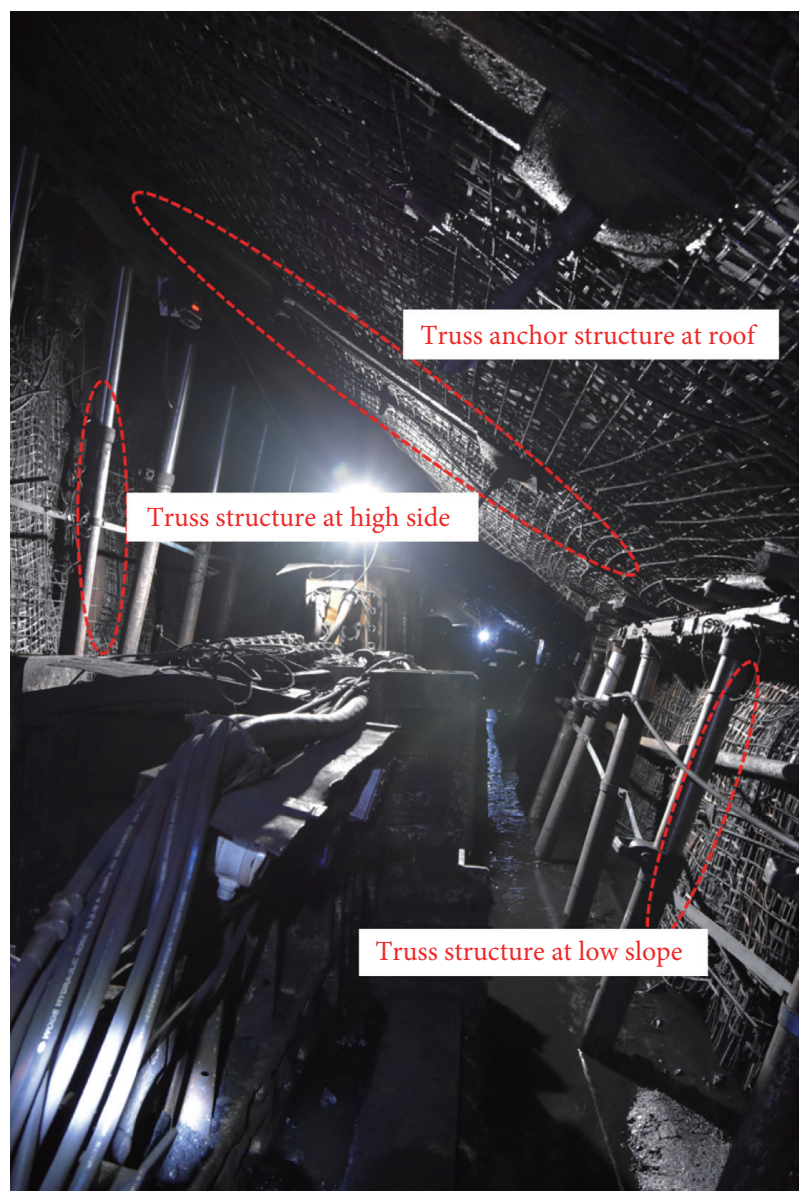

Figure 4: Transportation roadway with new truss support structure.

coal mine roadway, some inspirations have been obtained from the article $[19,20]$.

4.2. Analysis of Surrounding Rock Stress State. There was no other working face around the driving roadway during the period of this research. Hence, the analysis did not consider the influence of mining factors. To carry out a vivid comparative analysis of the stress state in the surrounding rock under different support forms, this research considered three different roadway states, including bare roadway without support, original support (without truss structure), and truss anchor cable support system.

4.2.1. Stress Analysis of Roof Strata. Figure 6 presents the numerical simulation results showing the stress profiles at the observation points on the roadway roof when under the three forms of support systems mentioned above, and the vertical stress distribution along the coal seam strike roadway section is shown in the figure. The stress distribution of the roof was approximately arched. The maximum tensile stress on the roof was $2.5 \mathrm{MPa}$, which did not reach the ultimate tensile strength of $3.6 \mathrm{MPa}$. The roof structure of the roadway was still intact and transferred the overlying load to the two coal sidewalls. The simulation results displayed in Figure 6 indicate that the range and intensity of the rock stress area at the top of the roadway were progressively increasing from case (a) with no roadway support to case (b) that is the original support state to case (c) that is the new truss anchor structure support state. Simultaneously, the rock stress at the top of the roadway was gradually decreasing, with the color becoming lighter, thus, indicating that the new support structure had successfully transferred the roadway confining pressure to the deeper rock area and reduced the roof pressure and the damage degree on the shorter coal sidewall. The objective in the new support design was achieved.

Vertical stress nephograms are shown in Figure 6 for the three kinds of roadway support forms. It is noteworthy that the maximum tensile stress of the roadway roof without support was $32.4 \mathrm{kPa}$, and the maximum compressive stress was $35.8 \mathrm{MPa}$. The maximum tensile stress of the roadway roof was $57.0 \mathrm{kPa}$, and the maximum compressive stress was $30.7 \mathrm{MPa}$. The maximum tensile stress of the roadway roof under truss support structure was $41.2 \mathrm{kPa}$, and the maximum compressive stress was $29.5 \mathrm{MPa}$. In contrast, on the premise of ensuring a good overall structure in the surrounding rock, the tensile stress of truss support structure was $27.7 \%$ lower than that of the non-truss anchor cable support structure. The maximum tensile strength of roof rock in the natural state was $2.1 \mathrm{MPa}$. Although the roof without support or truss support did not exceed the ultimate limit, there was no apparent damage.

The three different support systems gave differing stress distributions (Figures 6(a)-6(c)) in the surrounding rock. The red range of tensile stress around the roadway decreased in turn indicating that the tensile stress state of the roadway roof and the surrounding rock was weakening. This trend was extremely beneficial to the protection of the roof and surrounding rock. The roof stress in Figure 6(c) was within the ultimate tensile strength, and the distribution of deep compressive stress was the smallest among the three figures. This indicated that the stress in the shallow area around the roadway was controllable. The transfer stress in the deep area was reasonably distributed, and the support structure made 


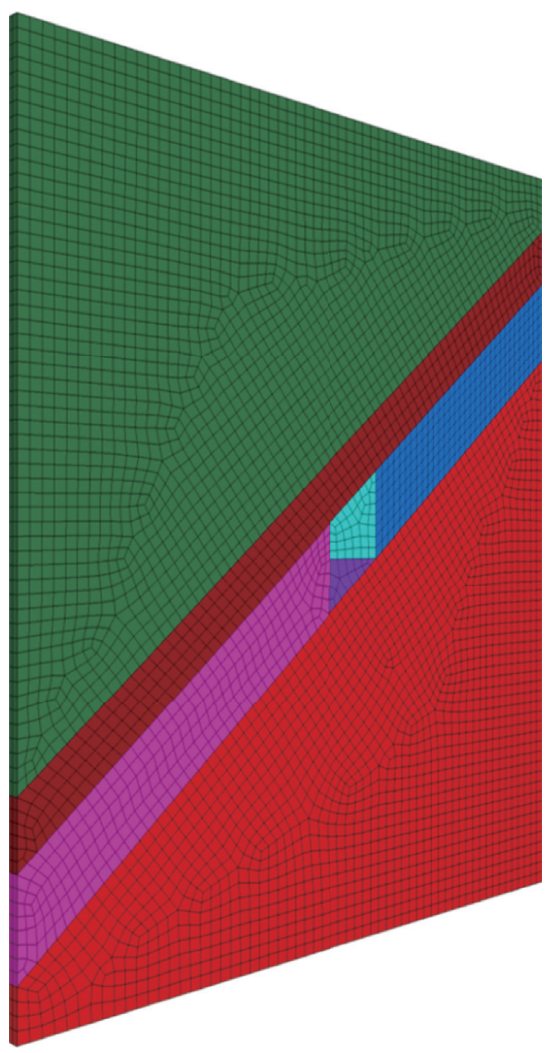

(a)

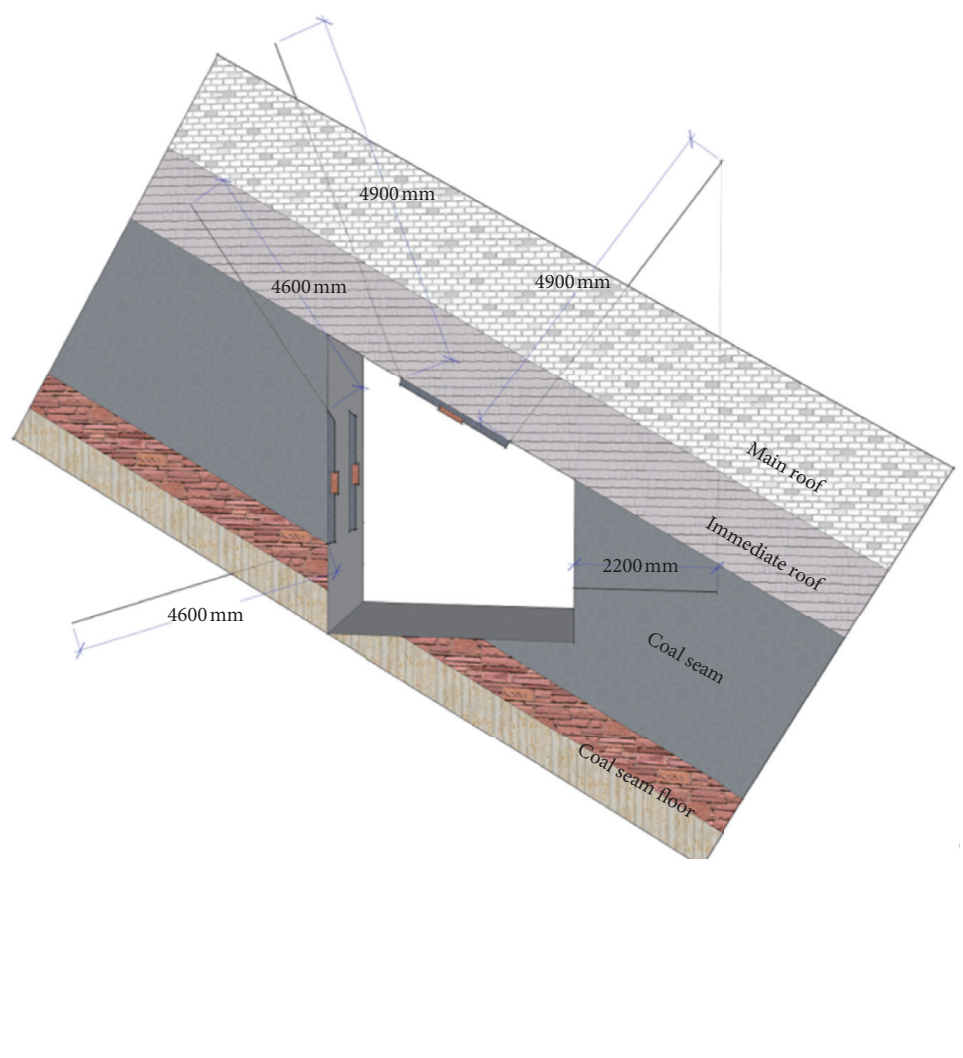

(b)

Figure 5: FLAC3D numerical modeling of the roadway and schematic diagram of roof-side anchor cable truss.

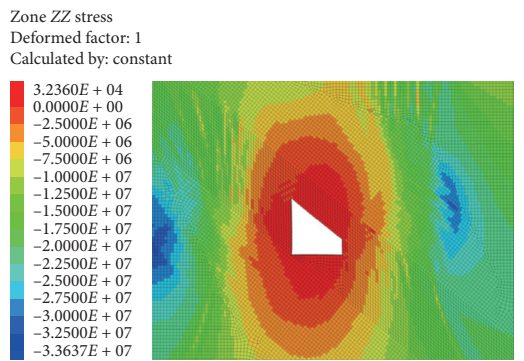

(a)

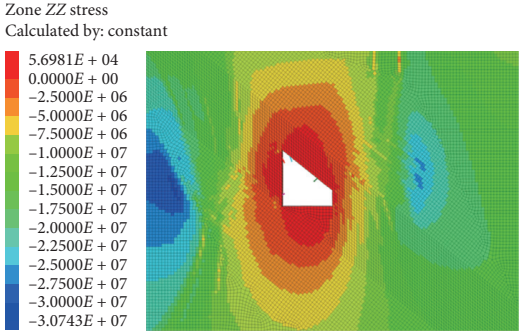

(b)
Zone $Z Z$ stress Calculated by: constant

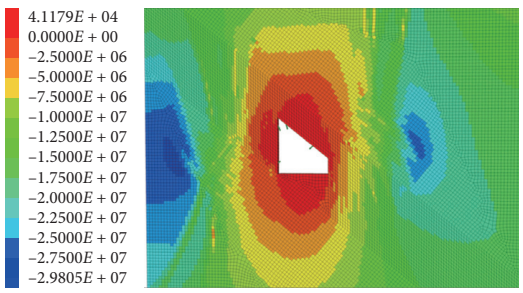

(c)

FiguRE 6: Vertical stress distribution of roadway under different support conditions. (a) No support state. (b) Supporting state of nontruss anchor cable. (c) Support state of truss anchor cable.

the overall stress of the roadway and surrounding rock more uniform, which was the best state desired for the actual construction.

Figure 7 displays the maximum subsidence displacement diagrams with the three different roof supports. According to these curves of the roadway roof subsidence, the maximum vertical displacement of the roof was $50 \mathrm{~mm}$ under the condition of no support, $16 \mathrm{~mm}$ under the condition of original support, and $15 \mathrm{~mm}$ under the state of new truss support. It showed that the roof structure was completely intact, the stress of overlying strata and original rock was not reflected on the roof, and the stress on the roof was effectively transferred to the coal sidewalls.
Figure 8 presents the comparison of the variations in the maximum effective stress of roadway roof under different support forms. These results show that the maximum compressive stress is $1 \mathrm{MPa}$ without support, $2.0 \mathrm{MPa}$ without truss cable support, and 2.4 MPa with truss structure support. This effective stress variation trend indicated that the roof stress state change from a tensile stress state to a compressive stress state was becoming more substantial. The compressive stress was far less than the limiting compressive strength value of the rock. The surrounding rock structure remained good and unchanged.

On the close comparative study of the effective stress history curves for the roof, it was evident that the effective 


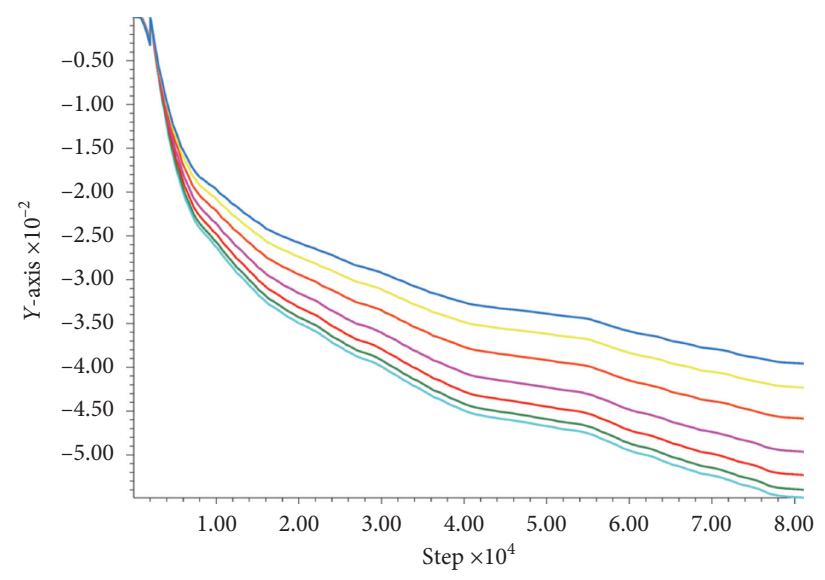

(a)

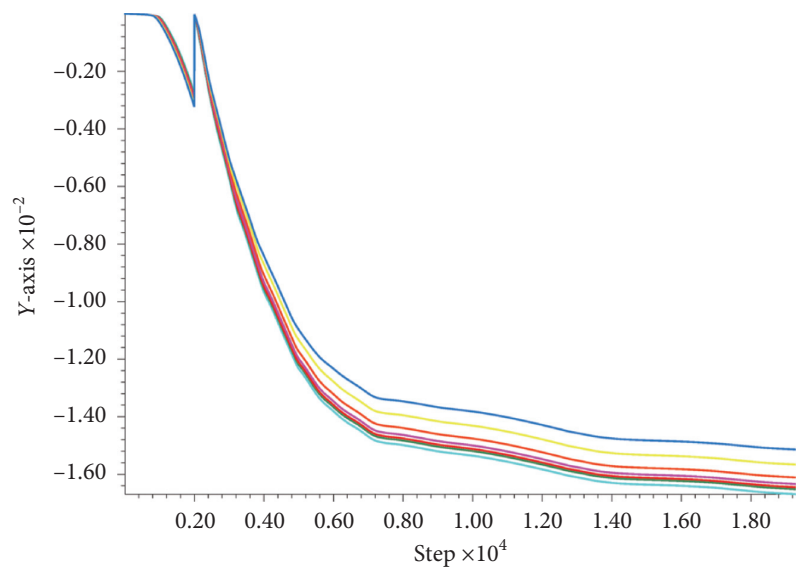

(b)

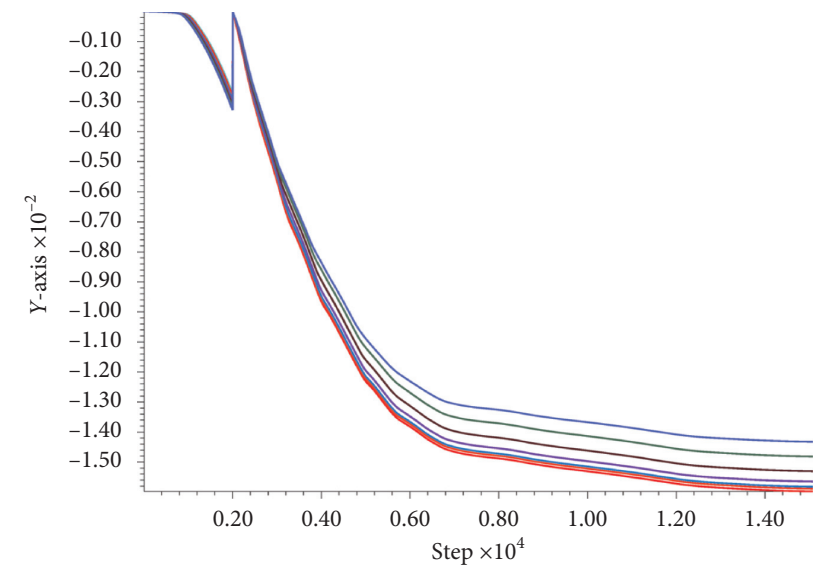

(c)

Figure 7: Maximum displacement of the roof under different support forms. (a) No support state. (b) Supporting state of non-truss anchor cable. (c) Support state of truss anchor cable.

stress in $Z$ direction for the roof with no support was 1.0 MPa. When the roof had the original support and under the new truss anchor supports, the effective stress on the roof was 1.5 MPa and 1.8 MPa, respectively. The Mohr-Coulomb failure criterion points out that the smaller the effective stress of rock is, the greater the fluid pressure is, and the easier it is for the rock to develop tensile failure. This confirmed that, of the three methods compared, the new truss support method provided an enhanced positive role in the roof control, with the overall state of the roof remaining more stable, less prone to be impaired. Thus, the new truss and anchor support was far more effective in maintaining the roof's integrity and roadway safety.

Figure 9 compares the roof displacement profiles resulting from the three different support systems studied. It presents that the roof displacement was reduced from $4.5 \mathrm{~cm}$ in no support to $1.9 \mathrm{~cm}$ in the state of no truss anchor support. The introduction of the anchor support to the truss structure reduced the roof displacement further to $1.8 \mathrm{~cm}$. Notably, the roof displacement of the truss structure did not give an extremely noticeable improvement compared with that of the nontruss anchor cable support structure system.
This was because the truss support structure had a better embodiment within the deeper stress transfer and distribution, giving the overall protection to the coal sidewall structure.

\subsubsection{Analysis of the Stress Levels on the Two Coal Sidewalls}

(1) Following the above mechanical analysis of the structure, Figure 10 illustrates the changes in the distributions of the plastic zone in the surrounding rock. It became evident that, under the action of vertical stress, the joint gap of the high coal sidewall produced staggered shear, and the tensile action made it reach towards the compression shear failure limit. The stress in the middle and upper areas of the high coal sidewall was concentrated, and this serious damage extended to the deeper part of the coal body. The maximum failure depth in the high coal sidewall was $2.65 \mathrm{~m}$. Therefore, the failure probability in the high sidewall was much greater than that in the low coal sidewall. 


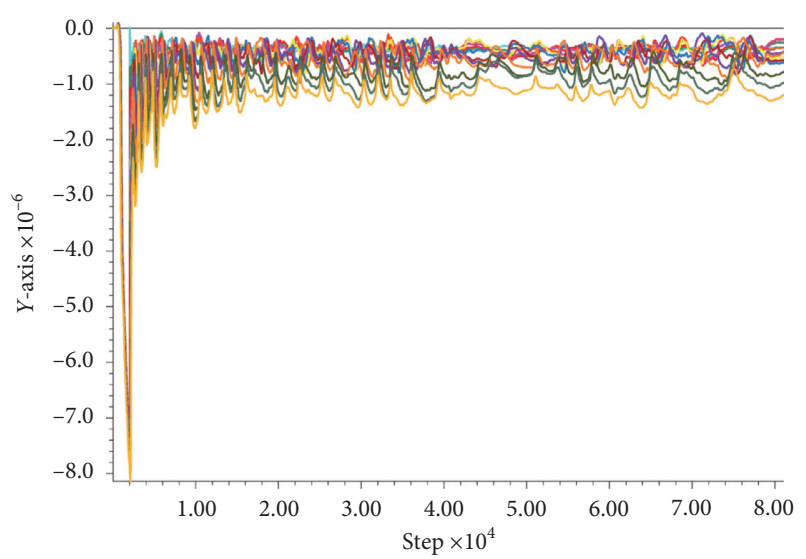

History

$\begin{array}{ll}- & 16 \mathrm{ZZ} \text { effective stress at }(14,0,18.75) \\ - & 17 \mathrm{ZZ} \text { effective stress at }(14,0,19) \\ - & 18 \mathrm{ZZ} \text { effective stress at }(14,0,19.25) \\ - & 19 \mathrm{ZZ} \text { effective stress at }(14,0,19.5) \\ - & 20 \mathrm{ZZ} \text { effective stress at }(14,0,19.75) \\ & 21 \mathrm{ZZ} \text { effective stress at }(14,0,20) \\ - & 22 \mathrm{ZZ} \text { effective stress at }(14,0,20.25) \\ - & 23 \mathrm{ZZ} \text { effective stress at }(14,0,20.5) \\ - & 24 \mathrm{ZZ} \text { effective stress at }(14,0,20.75) \\ - & 25 \mathrm{ZZ} \text { effective stress at }(14,0,21) \\ - & 26 \mathrm{ZZ} \text { effective stress at }(14,0,21.25) \\ - & 27 \mathrm{ZZ} \text { effective stress at }(14,0,21.5) \\ - & 28 \mathrm{ZZ} \text { effective stress at }(14,0,21.75) \\ & 29 \mathrm{ZZ} \text { effective stress at }(14,0,22) \\ \text { vs. Step } & \end{array}$

(a)

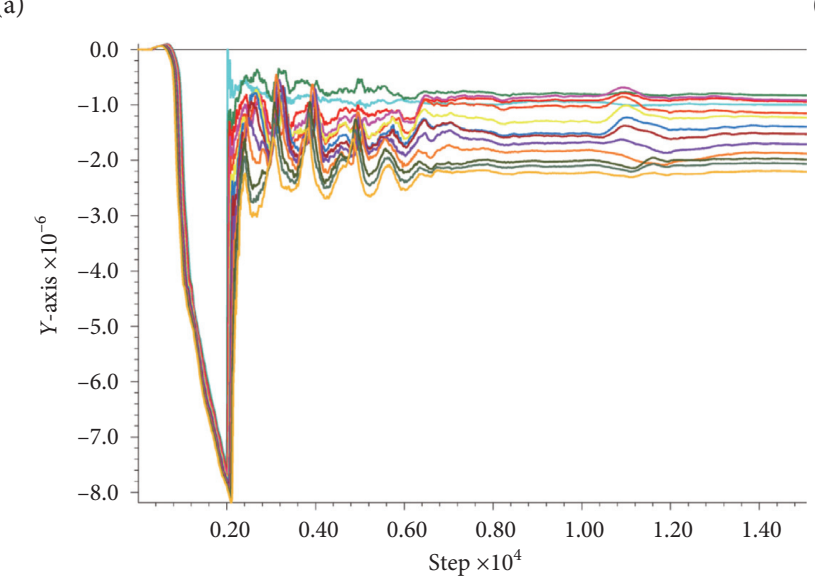

History

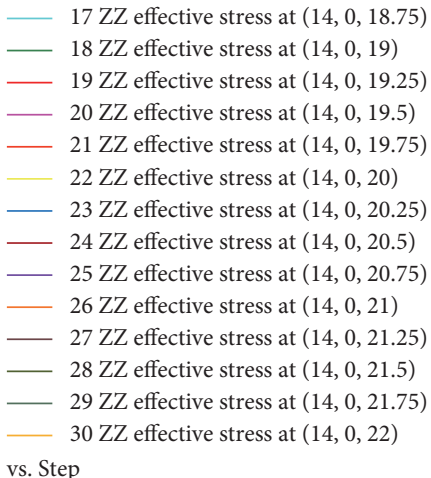

(c)

Figure 8: Variation of maximum effective stress of roadway roof. (a) No support state. (b) Supporting state of non-truss anchor cable. (c) Support state of truss anchor cable.

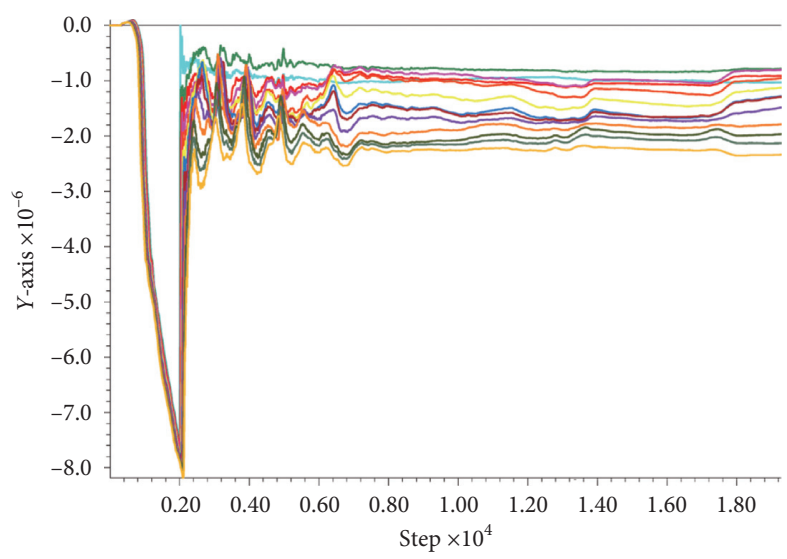

History

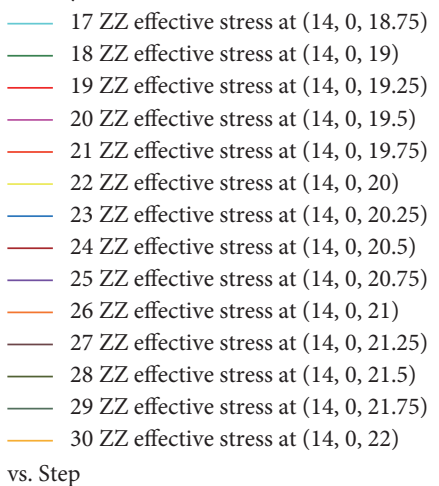

(b) 


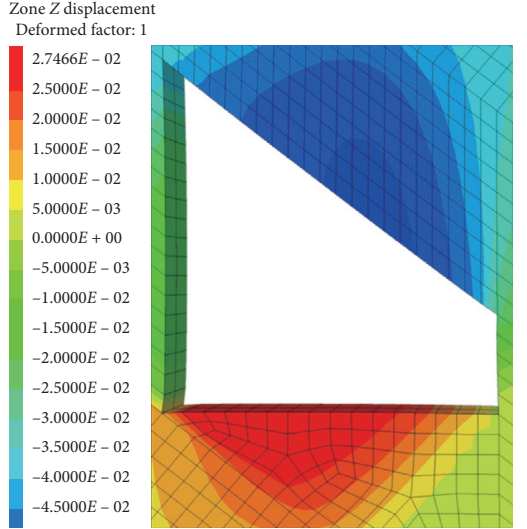

(a)

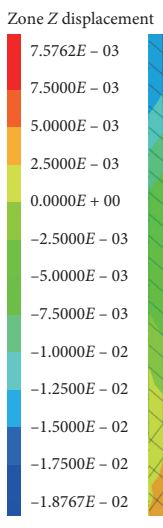

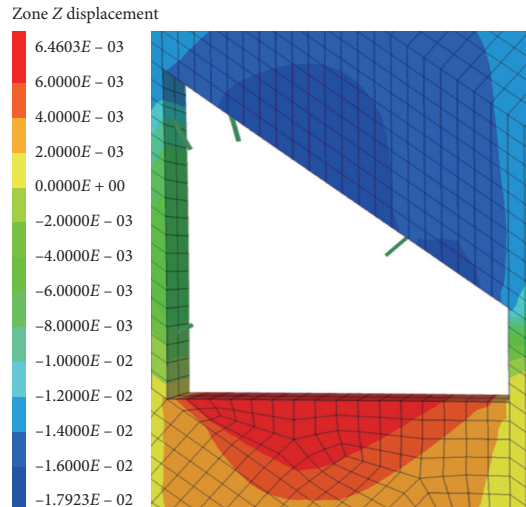

(c)

FiguRe 9: Maximum subsidence of roadway roof under different support forms. (a) No support state. (b) Supporting state of non-truss anchor cable. (c) Support state of truss anchor cable.
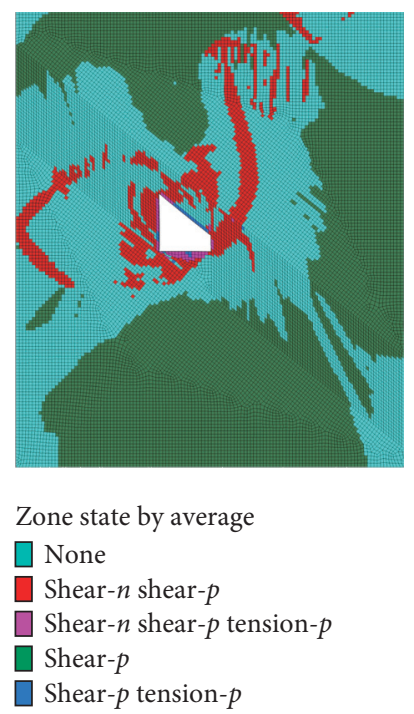

(a)
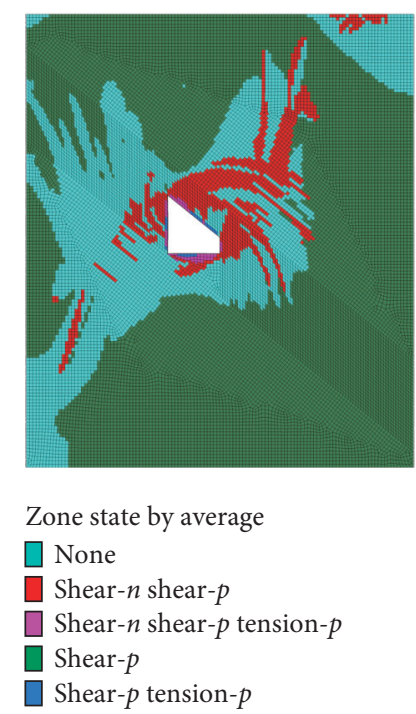

(b)

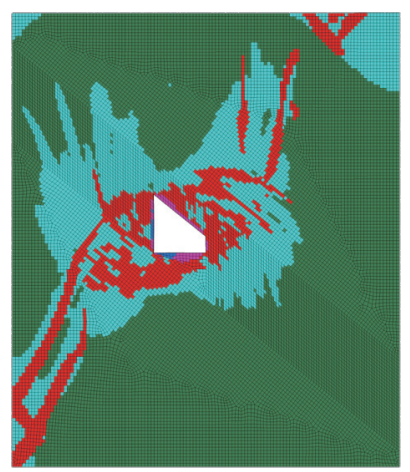

Zone state by average

$\square$ None

$\square$ Shear- $n$ shear- $p$

Shear- $n$ shear- $p$ tension- $p$

Shear- $p$

$\square$ Shear- $p$ tension- $p$

(c)

Figure 10: Distribution of the plastic zones in the rock surrounding the roadway. (a) No support. (b) Original support. (c) New combined support.

(2) The smaller height of the short coal sidewall and its relatively stable mechanical structure made the failure of the coal body not so apparent with the action of stress. The maximum failure depth in the short sidewall was $0.6 \mathrm{~m}$, which amounted to only $22.6 \%$ of the maximum failure depth of the high wall.

\subsection{Analysis of the Changes in the Plastic Zones}

(1) Considering the condition of the overall roadway structure, under different support conditions, the high coal sidewall was severely impaired by stress; the plastic zone was large, and the stress damage went deep into the coal wall. The anchor point within the support structure scheme needs to reach the stable rock layer before the support action can take effect. Increasing the intensity of support is the only means to control the roadway deformation. To enact this, the cost is high, and the controlling effect from the rock surrounding the roadway is poor.

(2) The results in Figure 10 show that the height of short coal seawall with a low slope was small, its structural stability was strong, the damage of the coal sidewall under stress was light, and consequently, the damage range of the plastic zone was generally tiny.

(3) The plastic zones for the roadway without support were concentrated around the roof and the coal sidewalls. The damage around the roadway was severe. It slightly reduced the stress regime in the rock surrounding the roadway (without truss anchor support), but the damage to the upper corner of the roof and the high sidewall was still apparent. 


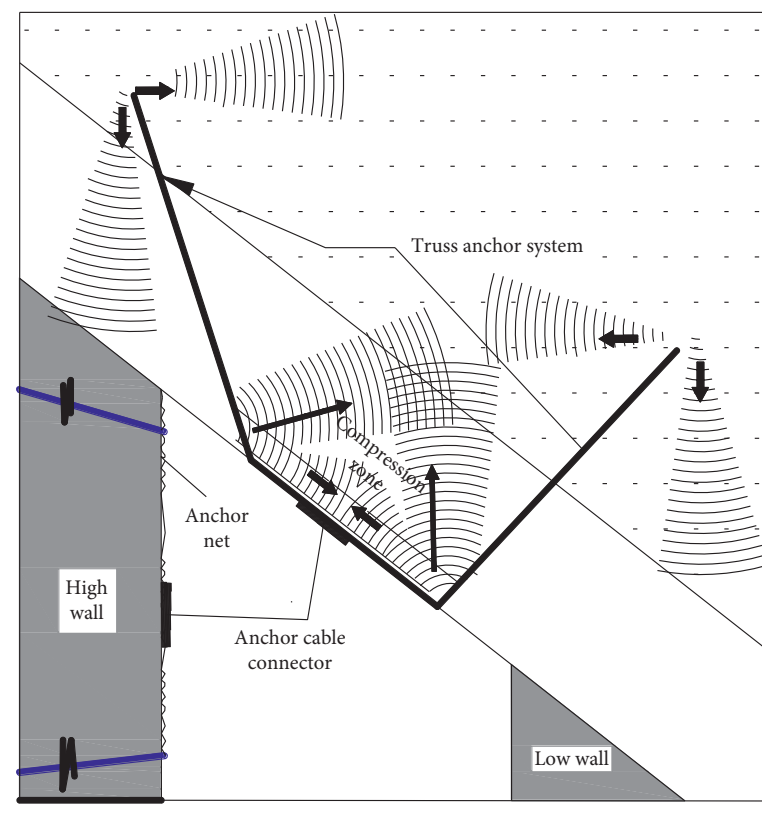

(a)

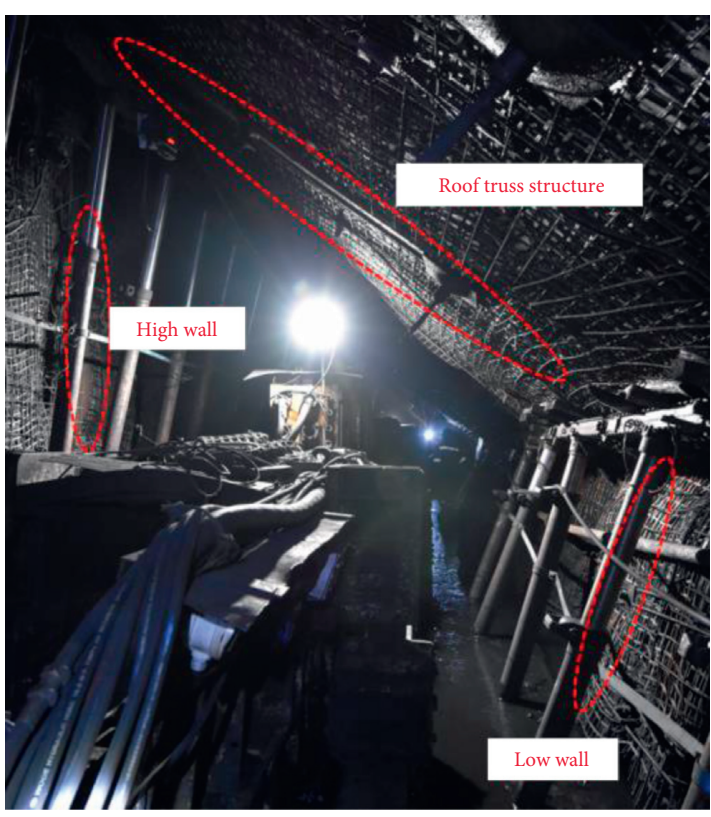

(b)

Figure 11: Stress diagram at the joint truss structure and field support.

However, the new truss support scheme significantly reduced the plastic zones on roof, and the plastic zone in the deep parts of the surrounding rock, especially in the deep part of the floor rock, was greatly increased. The support structure achieved the intended objectives of the original design of transferring the stress around the roadway to the deeper part of coal and rock to protect the safety of the driving roadway effectively.

\section{Engineering Application}

5.1. Thoughts on Control of the Rock Surrounding the Roadway. Mechanical structure analysis and the corresponding verification with numerical simulation facilitated identifying the areas that were prone to failure. These were the middle and upper portions of the roadway roof and the high wall. The combined support scheme strengthened the support for these critical parts of the roadway. The combined support technology from "truss anchor cable $+W$ steel belt + anchor rod + anchor mesh" was a further asset to the scheme. The pressure relief groove was excavated on the two sides of coal wall in time to avoid high stress concentrations. The roadway truss combined support technology formed an effective linkage structure to minimize the stress and deformation on the roof and the two sidewalls [21-25].

The supporting principle was mainly to form an encircling force structure in the zone of high-stress risk through the anchor cable and the connector anchored into the stable position of the roof. As a result, the bending roof subsidence and the broken gangue were mutually compressed and self-stabilized, forming a joint support structure with the coal and rock mass. This enabled the transfer of the stress, which initially acted on the two coal sidewalls to be directed to the stable primary roof rock. It then significantly reduced the pressure and deformation degree between the direct roof and coal sidewalls. Figure 11 illustrates this further through the schematic diagram for the combined support from the joint truss structure, and details of the truss anchor cable connector are as shown in Figure 12.

\subsection{Combined Support Scheme and Key Technical Parameters} The original roadway support was based on a negative and passive support technology. The combined support scheme mainly improved the support strength by increasing the support density. In the process of working face excavation, the abnormal mine pressure behavior characteristics of the roadway are as follows: bolt cable fracture and failure, the roadway roof subsidence, two sides approaching towards each other too much, the frequent occurrence of roof and coal sidewalls caving accidents, and the roof caving height varied from 1 to $4 \mathrm{~m}$. It confirmed that the effect of simply increasing the support density was not the ideal solution.

The new support adopted the "truss anchor cable $+W$ steel belt + anchor rod + anchor net" in the roof and high sidewall. This was a kind of positive and active technical support. Figure 13 shows the layout of the combined support. The specific supporting characteristics were as follows:

5.2.1. Bolting Parameters. Compared with the original support system, the new truss support method mainly increased the truss anchor cable structure reducing the anchor cable support density support and did not change the 


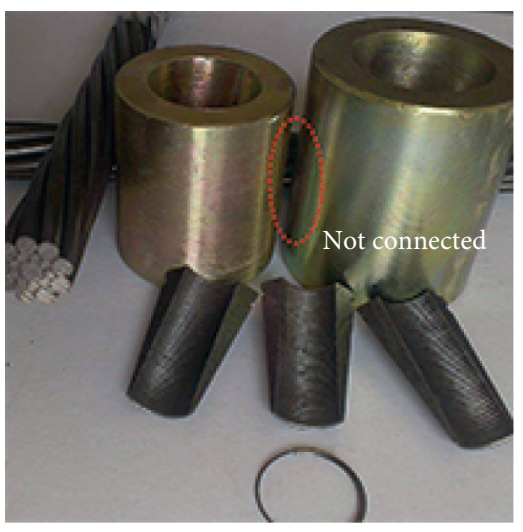

(a)

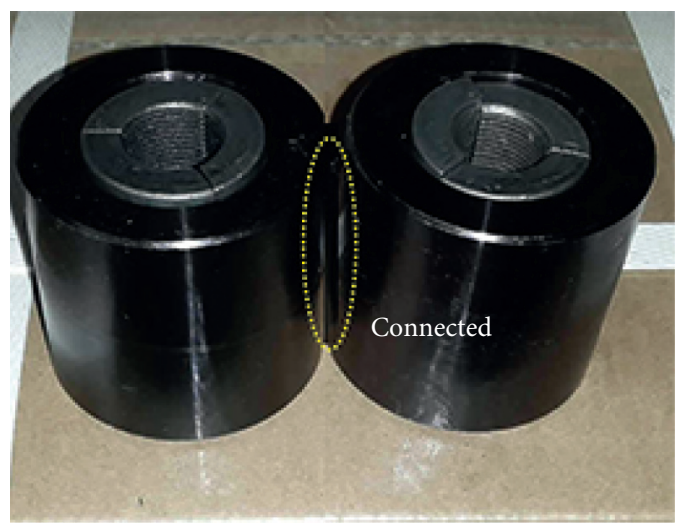

(b)

FIgURE 12: Views of the fastener of new and old supporting anchor cable. (a) Single anchor cable lock. (b) Truss anchor cable connector.

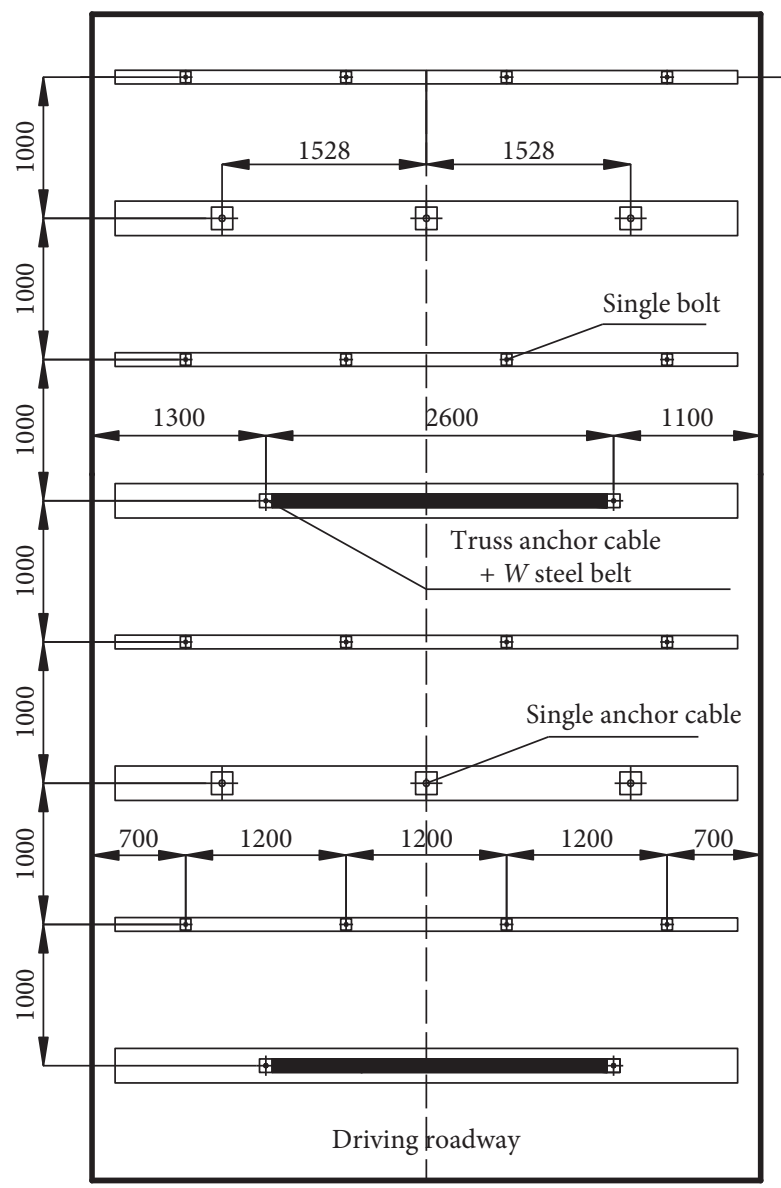

(a)

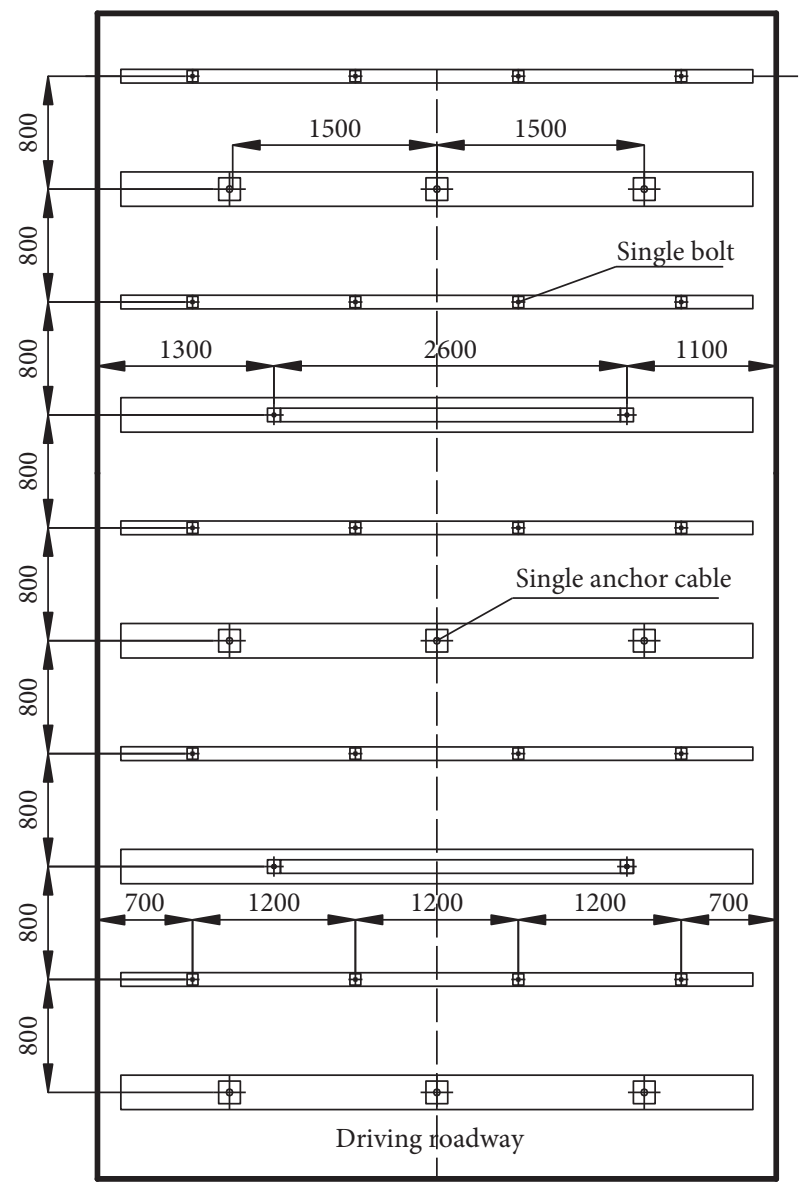

(b)

Figure 13: Top view of roadway roof support. (a) New roof support parameters. (b) Original roof support parameters.

support material. The top bolt was $22 \mathrm{~mm}$ in diameter and a $2800 \mathrm{~mm}$ long high-strength bolt with resin anchoring. The anchoring length was $1200 \mathrm{~mm}$; the pretightening torque was to be not less than $450 \mathrm{Nm}$. Whereas the original support bolt row spacing was $800 \mathrm{~mm}$, the new support structure increased the bolt row spacing to $1000 \mathrm{~mm}$, and the 
TABLE 2: Comparison of new and old support.

\begin{tabular}{|c|c|c|c|}
\hline $\begin{array}{l}\text { Parameter } \\
\text { Object }\end{array}$ & $\begin{array}{c}\text { Material parameter and anchorage } \\
\text { length }\end{array}$ & $\begin{array}{l}\text { Row spacing between original } \\
\text { supports }\end{array}$ & $\begin{array}{c}\text { Row spacing of new truss } \\
\text { support }\end{array}$ \\
\hline Roof bolt & $\Phi 22 \mathrm{~mm} \times 2800(1200) \mathrm{mm}$ & $1000 \mathrm{~mm} * 1000 \mathrm{~mm}$ & $1200 \mathrm{~mm} * 1000 \mathrm{~mm}$ \\
\hline Roof truss anchor cable & $\Phi 17.8 \mathrm{~mm} \times 6900(1800) \mathrm{mm}$ & Nothing & $2600 \mathrm{~mm} * 4000 \mathrm{~mm}$ \\
\hline High slope anchor & $\Phi 18 \mathrm{~mm} \times 2300(1200) \mathrm{mm}$ & $1000 \mathrm{~mm} * 1000 \mathrm{~mm}$ & $1200 \mathrm{~mm} * 1000 \mathrm{~mm}$ \\
\hline $\begin{array}{l}\text { High side truss anchor } \\
\text { cable }\end{array}$ & $\Phi 17.8 \mathrm{~mm} \times 6500(1800) \mathrm{mm}$ & Nothing & $2600 \mathrm{~mm} * 4000 \mathrm{~mm}$ \\
\hline Single roof anchor cable & $\Phi 21.8 \mathrm{~mm} \times 7000(1800) \mathrm{mm}$ & $2600 \mathrm{~mm} * 4000 \mathrm{~mm}$ & Nothing \\
\hline
\end{tabular}

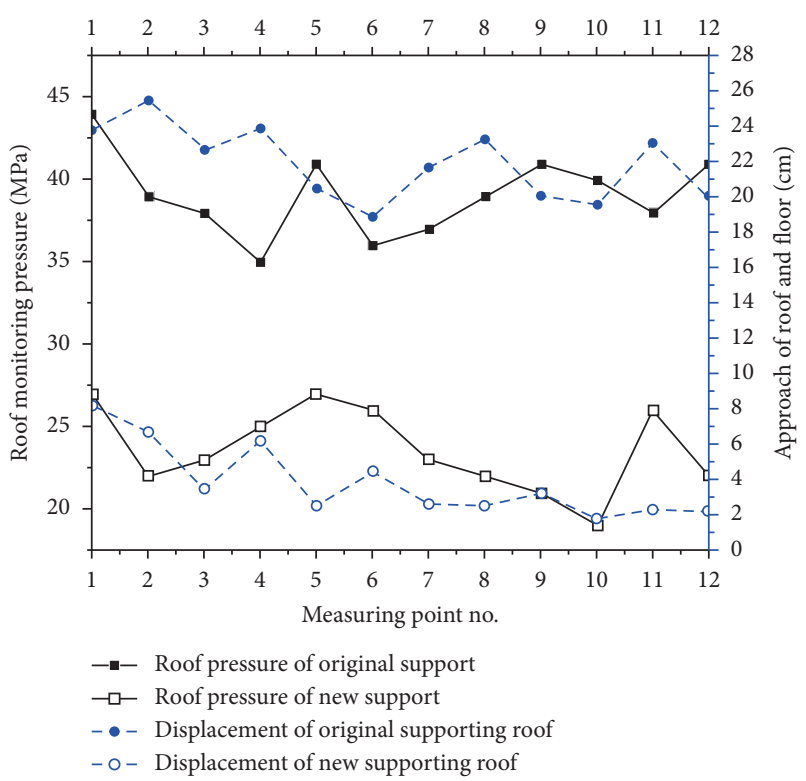

(a)

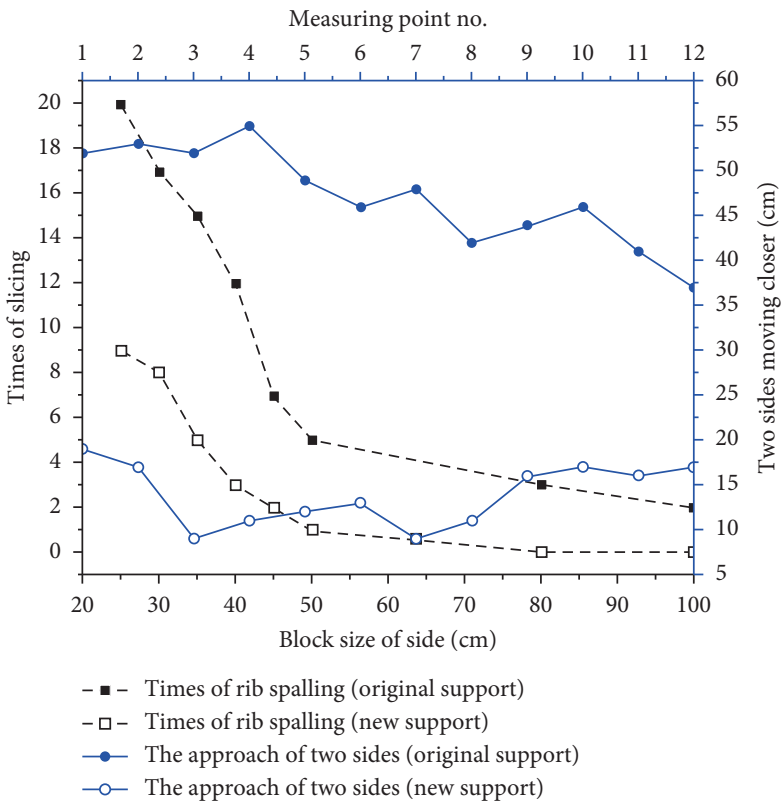

(b)

FIGURE 14: Biaxial curve of roadway monitoring parameters. (a) Stress and displacement of roadway roof. (b) Side slicing times and the distance between the two sides.

spacing arrangement comparison is shown in Figure 13. The high sidewall bolt was $18 \mathrm{~mm}$ in diameter. This ribbed steel bolt length was $2300 \mathrm{~mm}$, with an anchorage length of $1200 \mathrm{~mm}$. The pretightening torque was to be not less than $250 \mathrm{Nm}$. The distance between bolts and rows was $1000 \mathrm{~mm} * 1000 \mathrm{~mm}$ for the original support system. The new support system changed the corresponding spacing to $1200 \mathrm{~mm} * 1000 \mathrm{~mm}$. The comparison of new and old support parameters is shown in Table 2.

\subsubsection{Parameters of the Anchor Cable Support}

(1) The roof truss anchor cable was $17.8 \mathrm{~mm}$ in diameter and $6900 \mathrm{~mm}$ long. It was a high-strength anchor cable with a resin anchored cable length of $4900 \mathrm{~mm}$ deep into the roof section. An $1800 \mathrm{~mm}$ anchor section length, with a further $200 \mathrm{~mm}$ length, was reserved at the end of the anchor cable to overlap with the anchor cable connector. The anchor cable pretension was not to be less than $140 \mathrm{kN}$. The roof truss anchor cable row spacing was $4000 \mathrm{~mm}$, with the high sidewall anchor cable and the roof subtending an angle of $34^{\circ}$. The angle between the anchor cable and the roof at the low sidewall was $83^{\circ}$. The original support system had only one single roof anchor cable and had no truss anchor cable.

(2) The anchor cable on the high sidewall truss was $17.8 \mathrm{~mm}$ in diameter and $6500 \mathrm{~mm}$ long. It was a high-strength anchor cable with a resin anchored cable length of $4600 \mathrm{~mm}$ deep into the roof section. An $1800 \mathrm{~mm}$ anchor length, with a further $200 \mathrm{~mm}$ length, was reserved at the end of the anchor cable to overlap with the anchor cable connector. The anchor cable pretension was not to be less than $140 \mathrm{kN}$. The row spacing of the anchor cables on the high sidewall truss was $4000 \mathrm{~mm}$. The angle between the anchor cable to the roof and the coal wall was $74^{\circ}$, while the angle between the partial floor and the coal sidewall was $84^{\circ}$. There was no high sidewall truss anchor cable used in the original support system.

(3) We installed a single anchor cable between the two rows of truss anchor cables on the roof. This single 


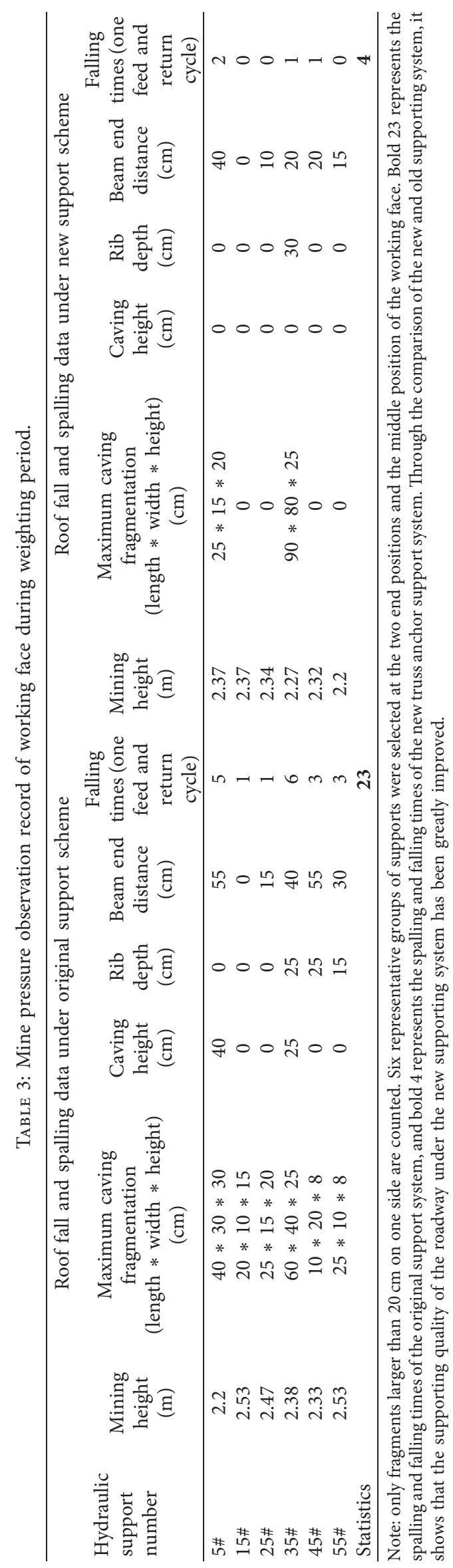


anchor cable was $21.8 \mathrm{~mm}$ in diameter, and the anchorage length of the high-strength anchor cable was $1800 \mathrm{~mm}$. The original roof support system also had a single anchor cable.

\subsection{Analysis of the Effects from the Combined Support Systems.} Dynamic measuring points were arranged along the roof and coal sidewalls at $20 \mathrm{~m}$ ahead of the working face. Four measuring points were in each group and arranged three groups making a total of 12 measuring points. The observed data from such measuring points were counted and presented in Figure 14. This figure compares the coal and rock mass deformation under the new and old support systems.

Figure 14 shows that the maximum roof pressure under the original support condition was $44 \mathrm{MPa}$, and that under the new support condition was $27 \mathrm{MPa}$, which amounts to $61.4 \%$ with that from the original support system. The maximum displacement of the roof and floor under the original support was $25.5 \mathrm{~cm}$. In contrast, the maximum displacement of roof and floor under the new support was only $8.2 \mathrm{~cm}$, which amounts to $32.2 \%$ of that from the original support system. Under the condition of the original support, the maximum approach of the two sides was $55 \mathrm{~cm}$. In contrast, under the needs of the new truss combined support system, the maximum approach of the two sides was only $19 \mathrm{~cm}$, which amounts to only $16.4 \%$ of that from the original support system. The overall effects on the roadway control were remarkable with the adoption of the new support system. According to the online monitoring system of mine pressure and the statistics of field production data, after the implementation of the new truss anchor cable, the stress of surrounding rock is stable and far below the bearing limit of roof, and the number of rock bursts in the mine is significantly reduced, from the original average of twice a month to zero. The stress stability of surrounding rock represents that the probability of impact is extremely small, which is verified by the field production. According to the comparison of the frequency of roof falling and spalling and the size of spalling in Table 3, it can be seen that the monthly average spalling frequency of the working face is reduced from 23 times to 4 times, the spalling frequency is reduced by $82.6 \%$, and the size of spalling and spalling is also greatly reduced. This also proves that the implementation of the new truss weakens the stress of surrounding rock and reduces the impact tendency of coal mine. During the whole mining period of the working face, there is no serious injury and impact accident of personnel and equipment, which effectively ensures the safety in production.

\section{Conclusions}

The following conclusions can be drawn from the research carried out on the comparative performance study on the roadway control support systems:

(1) The new type of combined truss support on the roof and high coal sidewalls presents circular compression support forming combined structural support with the body, and coal rock mass bearing together.
The above facilitated a noticeable control effect on the stability of the roadway.

(2) With the implementation of the new support technology, the maximum distance between the roof and floor was $8.2 \mathrm{~mm}$, and the maximum distance between the two coal sidewalls was $19 \mathrm{~mm}$, which amounts to $67.8 \%$ and $83.6 \%$, respectively, lower than that from the original support system, and the spalling frequency is reduced by $82.6 \%$ after the implementation of the new truss support measures. The above fully meets the needs of safe coal production.

(3) The anchorage position of the support body must break through the shallow coal and rock mass and go deep into the stable rock stratum to play the desired supporting role. Increasing the support density alone will not effectively improve the roadway control effect.

(4) The application of new combined support technology with the pressure relief groove was designed to enhance the control effect of the roof and the two coal sidewalls and excavated according to a situation imposed on a roadway to prevent stress accumulation. However, there is still room for optimizing technical parameters in the support scheme to carry out more in-depth research in the future.

\section{Data Availability}

The data used to support the findings of this study are available from the corresponding author upon request.

\section{Conflicts of Interest}

The authors declare that they have no conflicts of interest.

\section{Acknowledgments}

This research was funded by the Autonomous Region Teaching Reform Project in 2019 (no. XJJG201915) and Accurate Delay Rock Breaking Mechanism and Key Technology Innovation Team (no. 2020D14043).

\section{References}

[1] Y. Wu, K. Liu, D. Yun, P. Xie, and H. Wang, "Research progress on the safe and efficient mining technology of steeply dipping seam," Journal of China Coal Society, vol. 39, no. 8, pp. 1611-1618, 2014.

[2] Y. Deng and S. Wang, "Feasibility analysis of gob-side entry retaining on a working face in a steep coal seam," International Journal of Mining Science and Technology, vol. 24, no. 4, pp. 499-503, 2014.

[3] J. Wang and J. Jiao, "Criteria of support stability in mining of steeply inclined thick coal seam," International Journal of Rock Mechanics and Mining Sciences, vol. 82, pp. 22-35, 2016.

[4] G. Zhang and F. He, "Pillar width determination and surrounding rocks control of gob-side entry with large cross-section and fully mechanized mining," Rock and Soil Mechanics, vol. 37, no. 6, pp. 1721-1728+1736, 2016. 
[5] N. Wang, N. Zhang, F. Cui, J.-T. Cao, and X. P. Lai, "Characteristics of stope migration and roadway surrounding rock fracture for fully mechanized top-coal caving face in steeply dipping and extra-thick coal seam," Journal of China Coal Society, vol. 38, no. 8, pp. 1312-1318, 2013.

[6] Y. Zhang, P. Xie, and Y. Wu, "Deformation failure mechanism and the support technology of mining roadway under repeated mining in steeply inclined coal seam," Coal Engineering, vol. 52, no. 2, pp. 91-95, 2020.

[7] Z. Zheng and Z. Yang, "Study on reasonable coal-pillar width and surrounding-rock control of gob-side irregular roadway in inclined seam," Journal of Mining and Safety Engineering, vol. 36, no. 2, pp. 223-231, 2019.

[8] P. Shan, "Hybrid investigation of structural characteristics of coal-rock mass in mining steeply inclined coal seams," China Mining Magazine, vol. 28, no. 1, pp. 170-174+180, 2019.

[9] P. Gou and Y. Xin, "Stability analysis of roof structure in pitched seam gateway," Journal of China Coal Society, vol. 36, no. 10, pp. 1607-1611, 2011.

[10] X. Wang, Y. Wang, and D. Zhang, "Enhanced support technology for key area of the roadway in large, inclined angle "three-soft" coal seam," Journal of Mining and Safety Engineering, vol. 34, no. 2, pp. 208-213, 2017.

[11] X. Chen and X. Xiong, "Numerical simulation study on asymmetric characteristics of surrounding rock stress in right angle trapezoidal roadway," Coal Science and Technology, vol. 47, no. 4, pp. 57-62, 2019.

[12] F. He and L. Zhang, "Analysis of coupling control and stability of support structure in ladder shaped roadway," Safety in Coal Mines, vol. 47, no. 6, pp. 230-232+236, 2016.

[13] K. Gao, Study on Mining Deformation and Failure Law and Support Technology of Large Angle Special-Shaped Mining roadway, Xi'an University of Science and Technology, Xian's, China, 2018.

[14] S. Yin, W. Cai, F. He, D. Tian, and H. Shi, "Mechanism and application of parallel-arranged composed of truss cable and single cable with high preload," Journal of China University of Mining and Technology, vol. 43, no. 5, pp. 823-830, 2014.

[15] H. Tu, S. Tu, D. Zhu, D. Hao, K. Miao, and W. Wang, "Forcefracture characteristics of the roof above goaf in a steep coal seam: a case study of xintie coal mine," Geofluids, vol. 2019, Article ID 7639159, 11 pages, 2019.

[16] X. Qi, R. Wang, and W. Mi, "Failure characteristics and control technology of surrounding rock in deep coal seam roadway with large dip angle under the influence of weak structural plane," Advances in Civil Engineering, vol. 2020, Article ID 6623159, 17 pages, 2020.

[17] Y. Wu, P. Xie, and S. Ren, "Analysis of asymmetric structure around coal face of steeply dipping seam mining," Journal of China Coal Society, vol. 35, no. 2, pp. 182-184, 2010.

[18] T. Hong-Sheng, T. Shi-Hao, Z. Cun, Z. Lei, and Z. Xiao-Gang, "Characteristics of the roof $b$ and mine pressure manifestations during the mining of steep coal seam," Archives of Mining Sciences, vol. 62, no. 4, pp. 871-891, 2017.

[19] W. Zhang, T. Huo, C. Li, C. Wang, X. Qu, and C. Xin, "Characteristics of valuable $\mathrm{m}$ events in heading face of an underground coal mine using $\mathrm{m}$ system," Shock and Vibration, vol. 2021, Article ID 6683238, 10 pages, 2021.

[20] W. Zhang, N. Ma, J. Ma, C. Li, and J. Ren, "Mechanism of rock burst revealed by numerical simulation and energy calculation," Shock and Vibration, vol. 2020, Article ID 8862849, 15 pages, 2020.
[21] T. Zhao, "Surrounding rock failure analysis and its support in large mining height and thick top coal roadway," Safety in Coal Mines, vol. 49, no. 1, pp. 222-225+229, 2018.

[22] D. Wang, "Research on truss anchored cable and its application in retaining roadway along gob in steeply inclined thin coal-seam," Coal mining Technology, vol. 17, no. 3, pp. 46-48, 2012.

[23] H. Yan, F. He, and T. Xu, "Study of double-cable-truss controlling system for large section coal roadway of deep mine and its practice," Chinese Journal of Rock Mechanics and Engineering, vol. 31, no. 11, pp. 2248-2257, 2012.

[24] H. Zhao, J. Yao, F. He, H. Liu, and S. Zhang, "Application of prestress truss cable in large section coal roadway," Journal of China Coal Society, vol. 32, no. 10, pp. 1061-1065, 2007.

[25] S. Xie, F. He, S. Zhang, K. Li, and P. Li, "Technology of the truss cable combined support on large cross-section compound mudstone roof starting cut," China Mining Magazine, vol. 17, no. 9, pp. 90-92, 2008. 